\title{
MIOCENE LITHOLOGICAL, FORAMINIFERAL AND PALYNOLOGICAL DATA FROM THE BELVERDE BOREHOLE (PORTUGAL)
}

Trabajo presentado a las XVIII Jornadas de Paleontología y

II Congreso Ibérico de Paleontología

Universidad de Salamanca

Salamanca, 24-29 de Septiembre de 2002

\author{
Paulo LEGOINHA ${ }^{(1, \mathrm{a})}$, Lígia SOUSA ${ }^{(1, \mathrm{~b})}$, Jõ̃o \\ PAIS ${ }^{(1, \mathrm{c})}$, João FERREIRA ${ }^{(1, \mathrm{~d})}$, Ana RITA AMADO ${ }^{(1, \mathrm{e})}$ \\ and Isabel RIBEIRO ${ }^{(1)}$
}

\begin{abstract}
${ }^{1}$ Centro de Estudos Geológicos, Faculdade de Ciências e Tecnologia, Quinta da Torre, 2829-516 Caparica, Portugal. a) pal@fct.unl.pt b) 1s@fct.unl.pt c) jjp@fct.unl.pt d) jpf@fct.unl.pt e) arca@fct.unl.pt.
\end{abstract}

Legoinha, P., Sousa, L, Pais, J., Ferreira, J., Rita Amado, A. and Ribeiro, I. 2004. Miocene lithological, foraminiferal and palynological data from the Belverde borehole (Portugal). [Litología, foraminíferos y palinomorfos del Mioceno en el sondeo de Belverde (Portugal).] Revista Española de Paleontología, 19 (2), 243-250. ISSN 0213-6937.

\begin{abstract}
Preliminary data on lithostratigraphy and biostratigraphy of the Belverde borehole (http://www.dct.fct.unl.pt/ Sondagem/Sondagem/coluna/index_col.html) is presented. The borehole attained $619,77 \mathrm{~m}$ of depth, crossing $130 \mathrm{~m}$ of Plio-Pleistocene and $460 \mathrm{~m}$ of Miocene deposits. Main lithologies are fine sands, marls and biocalcarenites. A coral reef was recognized in the lower part of the borehole (530-585 m). Gamma ray, neutrons and sonic diagraphies were obtained. Eight ${ }^{87} \mathrm{Sr} /{ }^{86} \mathrm{Sr}$ isotopic ages (H. Elderfield, Cambridge University) and the presence of some of the main planktonic foraminifera markers were used to establish the chronostratigraphic framework. Planktonic spikes are related to the major transgressions of the Lower Tagus Basin (LTB): M. Burdigalian (sample Belv 459; $446 \mathrm{~m}$ ), L. Serravallian (Belv 76; $244 \mathrm{~m}$ ) and L. Tortonian (Belv 51, 202 m). Benthic assemblages are dominated by Ammonia, Elphidium and Nonion. Spores suggest a mild and humid climate during the uppermost Burdigalian to the Tortonian. Pollen is scarce. Thirty dinoflagellates taxa (26 Gonyaulacoids and 4 Peridinioids) have been identified, indicating coastal to shallow marine environments. In the uppermost Burdigalian to the Tortonian the presence of peridinioids and scarce acritarchs suggest influence of inshore to brackish environments. Several ${ }^{87} \mathrm{Sr}{ }^{86} \mathrm{Sr}$ ages obtained by H. Elderfield (Cambridge University) fit well with the biostratigraphy for the Lower an Middle Miocene, but values given by Howarth and Mcarthur (1997) are closer to the Upper Miocene biostratigraphic data.
\end{abstract}

Key words: Belverde borehole, Lower Tagus Basin, Portugal, Miocene, biostratigraphy, palynology, ${ }^{87} \mathrm{Sr} /{ }^{86} \mathrm{Sr}$ ages.

\section{RESUMEN}

En este trabajo se presentan los datos preliminares (litoestratigráficos y bioestratigráficos) obtenidos del análisis del sondeo de Belverde (http://www.dct.fct.unl.pt/Sondagem/Sondagem/coluna/index_col.html). Este sondeo alcanzó los 619,77 m de profundidad, atravesando $130 \mathrm{~m}$ de depósitos plio-pleistocenos y $460 \mathrm{~m}$ de depósitos miocenos. Las litologías encontradas se corresponden con arenas de grano fino, limos y biocalcarenitas. En la parte inferior de la perforación (530-585 m) se reconoció un nivel de corales. Se realizaron estudios de Rayos Gamma, neutrones y diagrafías acústicas. Para el establecimiento del marco cronoestratigráfico se usaron ocho edades de ${ }^{87} \mathrm{Sr} r{ }^{86} \mathrm{Sr}$, junto con foraminíferos planctónicos. La abundancia de foraminíferos plactónicos se relaciona con las principales transgresiones de la cuenca del Bajo Tajo (LTB): Burdigaliense medio (ejemplo, Belverde 459 a $446 \mathrm{~m}$ ), Serravaliense inferior (ejemplo, Belverde 76 a $244 \mathrm{~m}$ ) y Tortoniense inferior (ejemplo 51 a 202 m). Ammonia, Elphidium y Nonion son dominantes en las asociaciones bentónicas. Las esporas sugieren que desde el Burdigaliense hasta el Tortoniense predominó un clima suave y húmedo. El polen encontrado es escaso. Se han podido identificar 30 grupos taxónomicos (26 Gonyaulacoides y 4 Peridinioides) que indican ambientes 
costeros a marinos. La presencia de peridinioides y acritarcos escasos sugieren influencia de ambientes costeros salobres en el tramo Burdigaliense-Tortoniense. Las edades obtenidas en la relación ${ }^{87} \mathrm{Sr} /{ }^{86} \mathrm{Sr}$ por $\mathrm{H}$. Elderfield (Cambridge University) se encuadran bien con la bioestratigrafía en el Mioceno Inferior a Medio, mientras que para el Mioceno Superior las edades propuestas por Howarth y Mcarthur (1997) se correlacionan mejor con los datos de foraminiferos planctonicos.

\section{Palabras Claves: sondeo de Belverde, Cuenca del Bajo Tajo, Portugal, Mioceno, bioestratigrafía, palino-} logía, edades de ${ }^{87} \mathrm{Sr} /{ }^{86} \mathrm{Sr}$.

\section{INTRODUCTION}

The Lower Tagus Basin (LTB) presents a rather complete marine and continental Cenozoic sedimentary record. It has been the object of scientific research for a long time, namely since Teodoro de Almeida's "Recreasaõ Filozofica" (1762). Several geologic and paleontologic studies followed during the $19^{\text {th }}$ century, either by foreign (D. Sharpe, W. Sowerby, W.-L. von Eschwege, etc) or Portuguese researchers (José Bonifácio de Andrada e Silva, A. Vandelli, F. Pereira da Costa and others, with a special reference to J. C. Berkeley Cotter, in the early $20^{\text {th }}$ century). Also relevant were the works of Paul Choffat and Georges Zbyszewski.

Concerning the Neogene, it allows a good knowledge of the stratigraphy, paleontology, geochemistry and paleoclimates. Namely for the Miocene, direct correlation between marine and continental biomarkers can be obtained. Further relevancy is added by its peculiar geographic situation on the interface between the western Atlantic and mediterranean domains, and in some way influenced by the North American margin. An impressive volume of multidisciplinary data is presently available (Pais, 2004, Fig. 2, in this volume). Among others, the contribution of the PRAXIS XXI Project "Neogénico da margem atlântica da Ibéria e transformações globais" must be stressed (Antunes et al., 1996, 1999).

Until now, studies have been based on outcroping units although not representing the total infill of the Lower Tagus Basin. In order to get the most continuous record of the Miocene deposits a new research project (POCTI/ $32345 /$ CTA/2000) was proposed. The aim of this project was to make a borehole with continuous sampling through Neogene reaching the topmost Paleogene, drilled on the inner region of the Lower Tagus gulf but still in the area of Atlantic influence.

\section{LOCATION}

The drilling location was selected from seismic profiles, in order to allow the extrapolation of the results to the inner regions of the basin by following the main reflectors. The chosen location was at Belverde (Peninsula de Setúbal, coordinates: $38^{\circ} 35^{\prime} 54,1^{\prime \prime}$ N; $9^{\circ} 8^{\prime} 24,7^{\prime}$ ' W).

\section{MATERIALS AND METHODS}

Drilling work took place from $21^{\text {st }}$ March to the end of December 2001.

Four hundred samples were collected for micropaleontological, palynological and clay minerals studies. Samples for foraminiferal study were disaggregated with a $\mathrm{H}_{2} \mathrm{O}_{2}$ solution, and washed in a $125 \mu \mathrm{m}$ sieve. Preparation of samples for palynological study followed standard procedures with wet sieving through $150 \mu \mathrm{m}$ sieve onto a $25 \mu \mathrm{m}$. The fraction containing palynomorphs was separated using $\mathrm{Zn}_{2} \mathrm{Cl}$ heavy-liquid. The residues were mounted in glycerin jelly.

Natural gamma ray, neutron-neutron, temperature and geophysical logs were made. The Geothermal gradient log was calculated after temperature log. SP, SPR and sonic logs were obtained for two small sections in upper and lower parts of the Miocene deposits.

\section{LITHOLOGY AND PALAEONTOLOGY}

The borehole reached $619,77 \mathrm{~m}$. It crossed $130,31 \mathrm{~m}$ of Plio-Pleistocene continental deposits, $460 \mathrm{~m}$ of Miocene (mainly marine deposits; including marsh ones). In the lower part of the borehole (530-585 m), a coral reef was recognised. This coral reef overlays red continental conglomeratic deposits probably representing the Benfica Group historically supposed to be of Paleogene age.

Miocene (from $130 \mathrm{~m}$ to $590 \mathrm{~m}$ ) main lithologies are fine sands, marls and biocalcarenites. In the lower part, marly limestones prevail while sands become predominant in the upper part. Marls are abundant in the Middle Burdigalian and Lower Serravallian.

Mica is present, except in the lower part of the borehole (Aquitanian). Sediments are strongly micaceous in the Upper Burdigalian and from Middle Serravallian to Lower Tortonian. After Langhian biotite becomes much more frequent.

Coal fragments are present in lower part (Aquitanian and Burdigalian) but almost inexistent in the upper part (Langhian to Tortonian).

Macrofossils are frequent along the borehole, but they are absent from $175 \mathrm{~m}$ to $193 \mathrm{~m}$ (Tortonian) and in the Upper Aquitanian (515-528 m).

A coral reef was recognized in the lower part of the borehole $(530-585 \mathrm{~m})$. Corals are also present in the Burdigalian (458-480 m) and Langhian (275-308 m).

Algae are frequent, increasing after the Middle Burdigalian. 


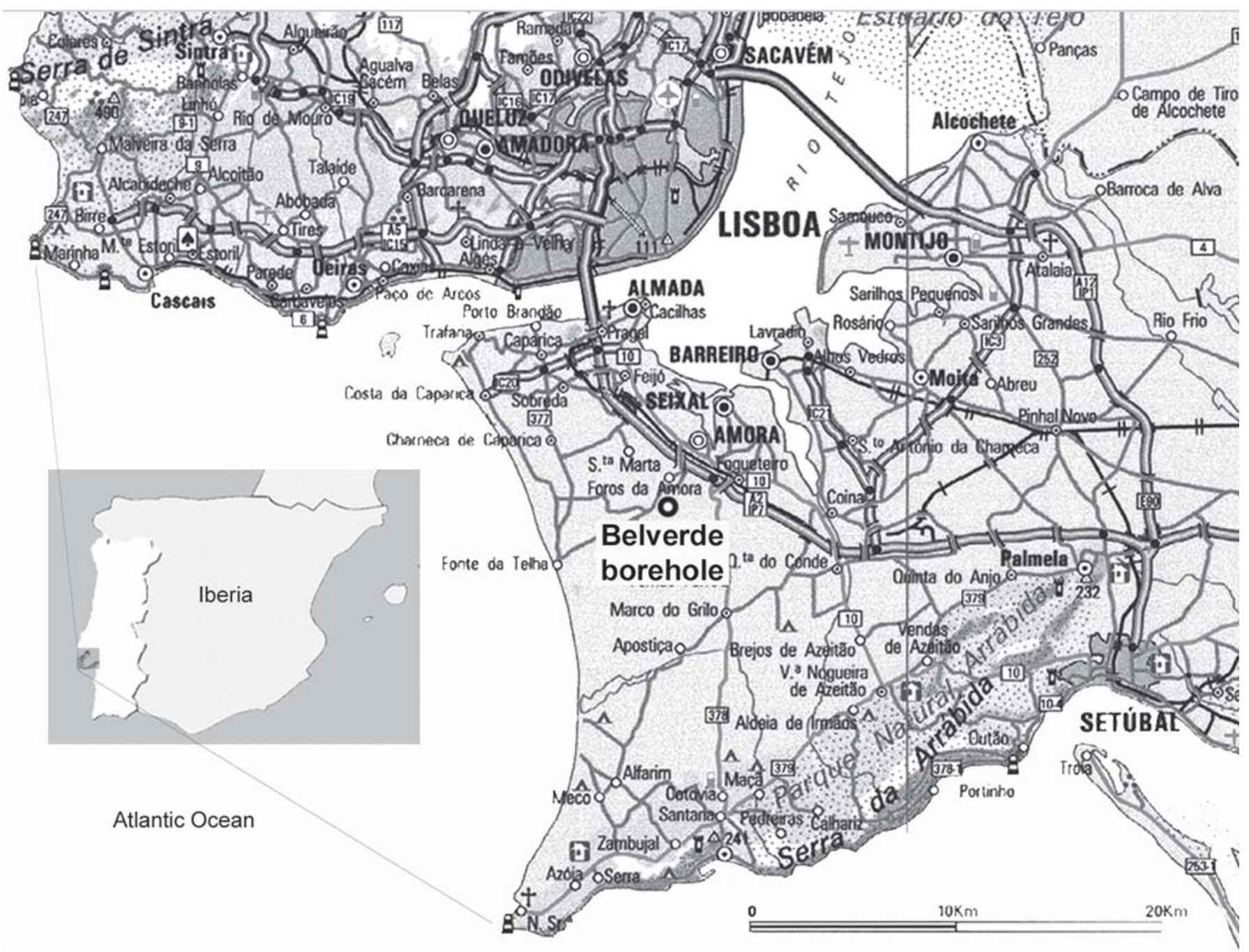

Figure 1. Location of Belverde borehole.

\section{DIAGRAPHIES (Fig. 2)}

Sonic $\log$ s (and, generically, neutron logs) reflect sediments porosity, being the higher acoustic velocities often related with compact/massive levels (as siltstones and/or limestones and rather fossiliferous marly layers) and smaller values with porous ones (silty sandstones, fossiliferous and with scarce clay content levels and biocalcarenites). As indicative, we obtained the mean values of $2000-3000 \mathrm{~m} / \mathrm{s}$ to the higher velocities, and 5000 $8000 \mathrm{~m} / \mathrm{s}$ to the lowest ones.

Concerning gamma ray logs, the spikes of radiation can be correlated with marly layers often fossiliferous and micaceous (presence of radioactive micas). Minimum values of gamma ray can be correlated to the boundaries of depositional sequences previously defined for the Lower Tagus Basin (Antunes et al., 1999, 2000; Pais et al., 2002). A correlation between gamma ray cycles and depositional sequences is presented in Fig. 2.

\section{BIOSTRATIGRAPHY (Fig. 3)}

Planktonic foraminifera spikes are related to the major transgressions of the Lower Tagus Basin (LTB): Middle Burdigalian (sample Belv 459; $446 \mathrm{~m}$ ), Lower Serravallian (Belv 76; $244 \mathrm{~m}$ ) and Lower Tortonian (Belv 51, $202 \mathrm{~m}$ ) (Legoinha et al., 2002).

In the marls at 440-453 m, Globigerinoides altapertura, Globigerinoides subquadratus and Globorotalia acrostoma were found indicating the Burdigalian (N6). These sediments are related to the Lower Miocene main transgression of the LTB.

Globigerinoides bisphericus (Belv 161, $342 \mathrm{~m}$ ) allow correlation to the Upper Burdigalian (N7).

Praeorbulina transitoria (Belv 134, $311 \mathrm{~m}$ ) and Praeorbulina glomerosa (Belv 104, 278m) occur in the Langhian (N8).

First occurrence of Orbulina universa (Belv 96, 267 m) was used to place the Langhian/Serravallian boundary (N9). Globorotalia scitula and Globorotalia periphero- 


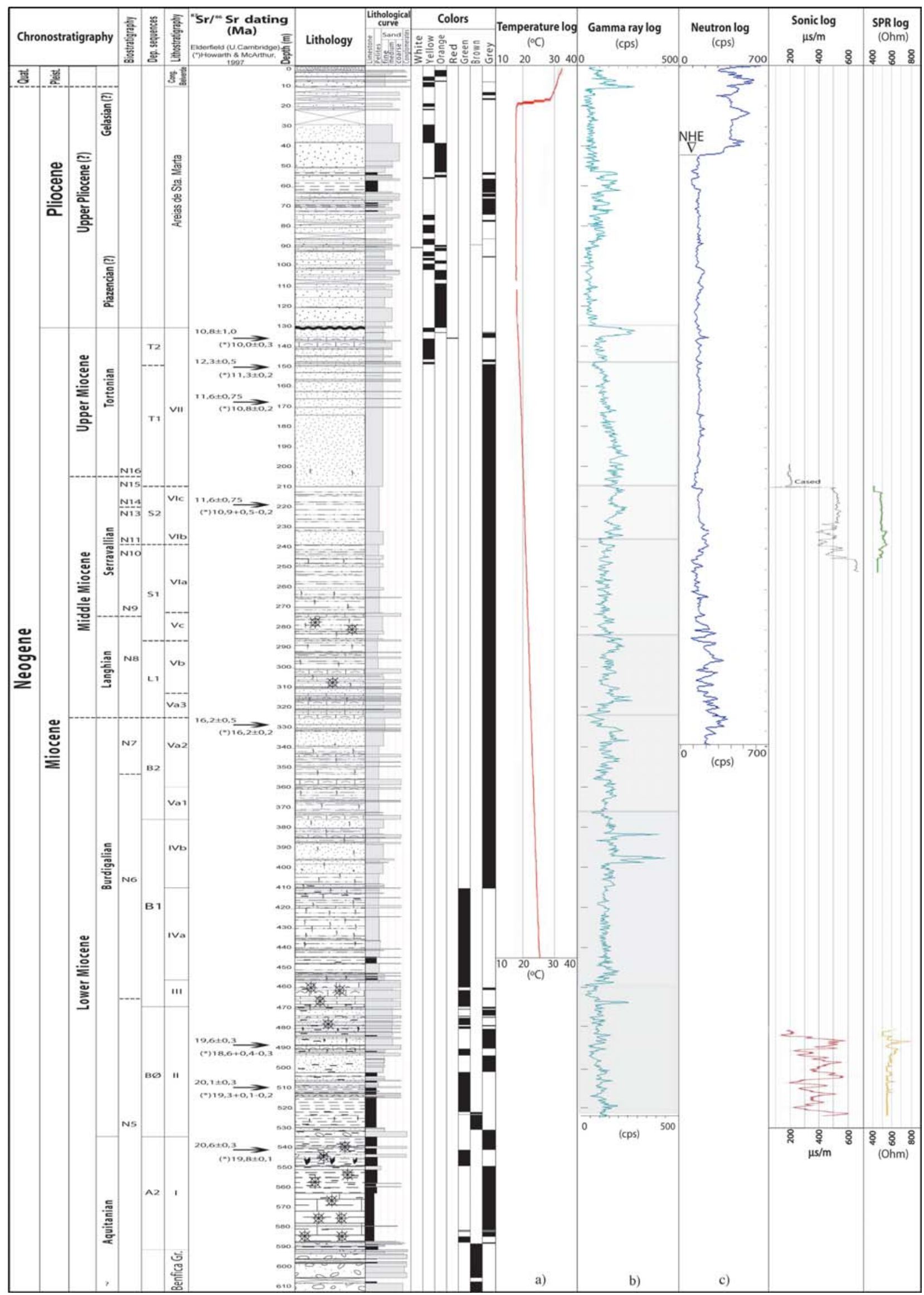

Figure 2. Lithology, diagraphies, depositional sequences and chronostratigraphical framework of the Belverde borehole. 


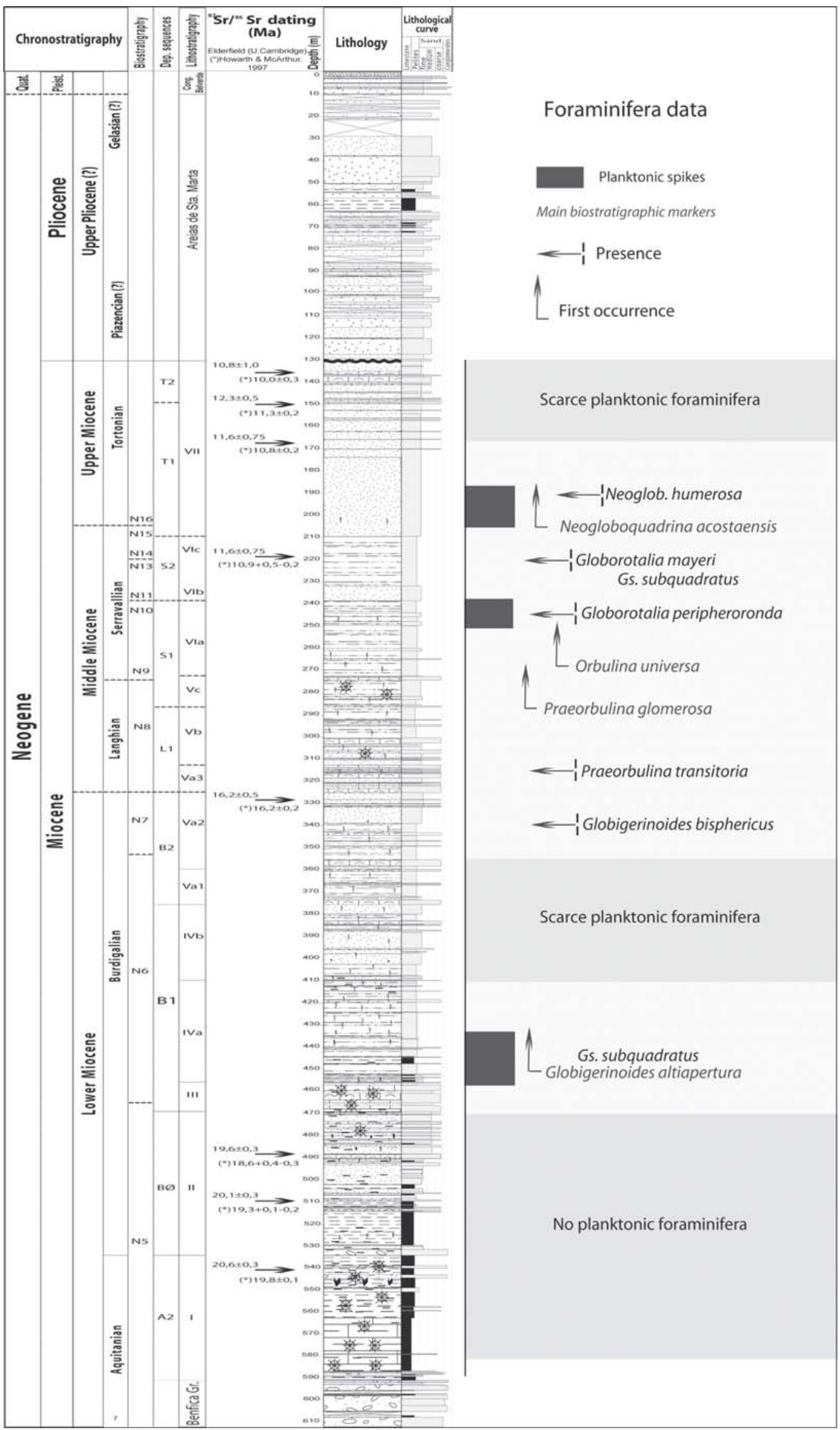

Figure 3. Biostratigraphy of the Belverde borehole based on planktonic foraminifera and ${ }^{87} \mathrm{Sr} /{ }^{86} \mathrm{Sr}$ ages. 


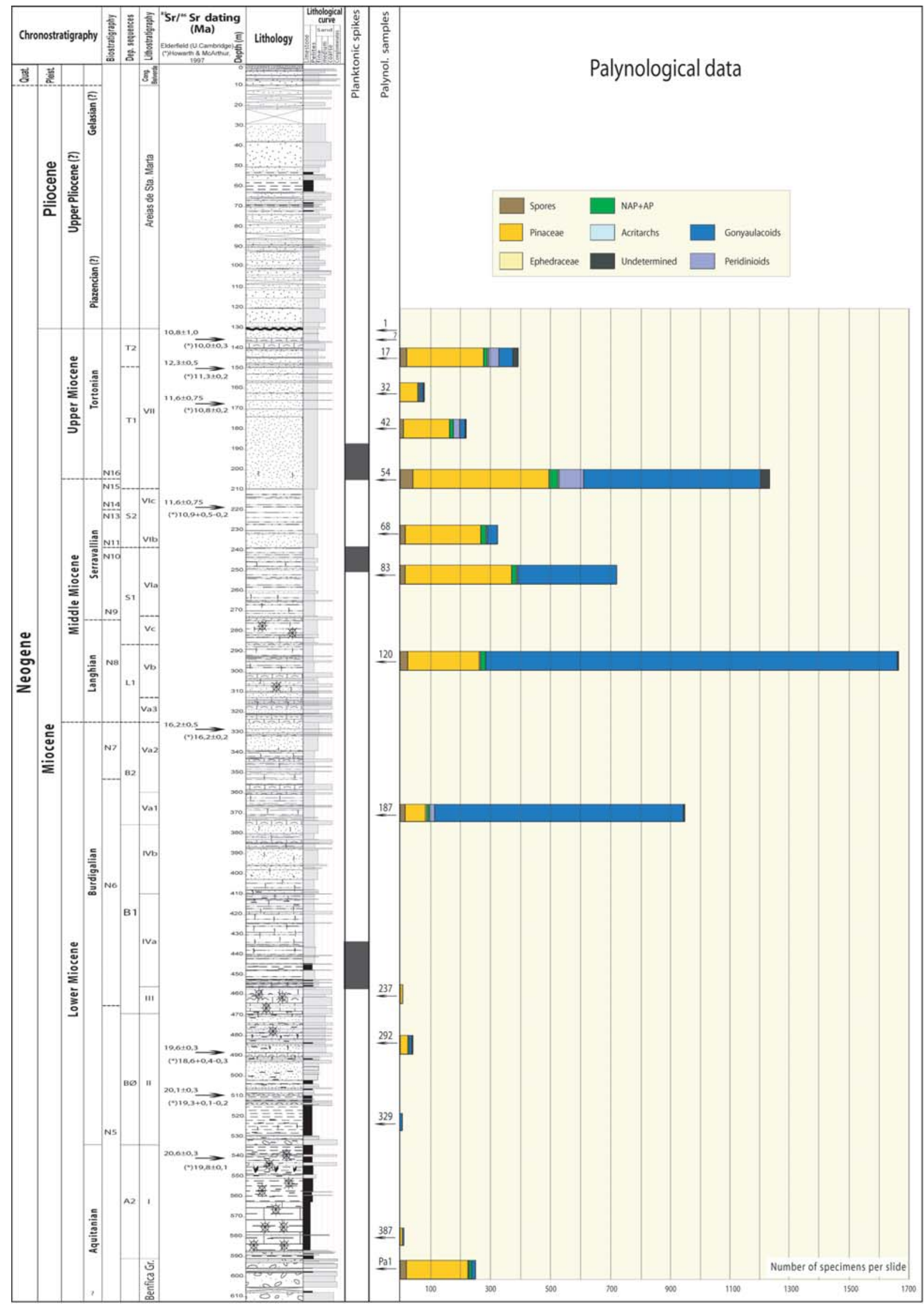

Figure 4. Palynomorphs distribution from the Belverde borehole. 
ronda $(\leq \mathrm{N} 10)$ are present (Belv 76, $244 \mathrm{~m})$. Uvigerina is frequent. These sediments are related to the Serravallian main transgression of the LTB.

Globigerinoides subquadratus, Globorotalia mayeri, G. menardii and Orbulina universa occur in the interval from Belv $61(218 \mathrm{~m})$ to Belv $70(235 \mathrm{~m})$ characterizing N11 to N13 (Serravallian).

Neogloboquadrina acostaensis is frequent above Belv 55 (207 m) pointing out to the Tortonian (N16); Neogloboquadrina humerosa is present in Belv 45.

Planktonic foraminifera are abundant and well preserved from Belv 55 to Belv 45 ( $210 \mathrm{~m}$ to $190 \mathrm{~m}$ ), suggesting a maximum of depth related to the Lower Tortonian transgression of the LTB. Planktonic foraminifera are scarce in the upper $50 \mathrm{~m}$ of the Miocene succession, indicating less influence of the sea.

\section{BENTHONIC FORAMINIFERA}

In the lower part of the borehole planktonic foraminifera are scarce or absent (460 to $595 \mathrm{~m}$ ). Ammonia, Elphidium and Nonion are predominant in the benthic assemblages. Amphistegina and Cibicides occur sporadically. Fragmented shells, brown due to limonitisation are frequent in some samples. Abundant miliolids occur in a few samples from 530 to $550 \mathrm{~m}$.

In some levels benthic shells appear abraded and/or recristalized. At Belv $13(143 \mathrm{~m})$ benthic foraminifera are scarce. Ammonia and Nonion constitute all the assemblage of the uppermost samples.

\section{PALYNOLOGY (Fig. 4)}

Concerning palynomorphs, 15 samples were selected (table 1).

Belv 1 and 7 are almost sterile (Tortonian). In Belv 387 (Aquitanian), 329, 292, 237 (Lower Tortonian) and Belv 32 (Middle Tortonian) the palynomorphs are scarce $(<100$ forms). They are abundant (250-1660 forms) in the other samples. Dinoflagellates are predominant over spores/ pollen in Belv 187, 120 and 54. In Pa1, Belv 83, 68, 42, 32 and 17 spores/pollen prevail.

Spores (Sphagnaceae, Anthocerotaceae, Ricciacea, Selaginellaceae, Pteridaceae) suggest a mild and humid climate (Belv 187, 120, 83, 68, 54, 42, 32, 17 - uppermost Burdigalian to uppermost Tortonian). Pinaceae are abundant in the samples of Middle and Upper Miocene but, in Belv 387, 329, 237, 7 and Pa1, it is very scarce. Ephedraceae is scarce (Pa1, Belv 187, 120, 17). Angiosperm arboreal pollen are scarce $(n<6)$. Non arboreal pollen occur in all samples except Belv 329, 7 and 1; they are represented during uppermost Burdigalian (Pa1, Belv

\begin{tabular}{|c|c|c|c|}
\hline Series & Stages & $\begin{array}{c}\text { Samples } \\
\text { (Belv) }\end{array}$ & $\begin{array}{c}\text { Depth } \\
\text { (m) }\end{array}$ \\
\hline \multirow{15}{*}{ Miocene } & \multirow{6}{*}{ Tortonian } & 1 & 130,35 \\
\hline & & 7 & 135,66 \\
\hline & & 17 & 146,59 \\
\hline & & 32 & 162,18 \\
\hline & & 42 & 179,51 \\
\hline & & 54 & 205,86 \\
\hline & \multirow[t]{2}{*}{ Serravallian } & 68 & 231,88 \\
\hline & & 83 & 251,28 \\
\hline & Langhian & 120 & 295,58 \\
\hline & \multirow{4}{*}{ Burdigalian } & 187 & 370,55 \\
\hline & & 237 & 460,85 \\
\hline & & 292 & 481,15 \\
\hline & & 329 & 520,62 \\
\hline & \multirow[t]{2}{*}{ Aquitanian } & 387 & 580,60 \\
\hline & & $\mathrm{Pal}$ & 595,97 \\
\hline
\end{tabular}

Table 1. Palynological samples.

187), Middle (Belv 120, 83, 68) and Upper Miocene (Belv $54,17)$. Acritarchs are few $(\mathrm{n}<4)$; only Cyclopsiella grano$s a$ and Pterospermella sp. occur in Upper Miocene (Belv 292, 187, 54, 42): Peridinioids occur in the uppermost Burdigalian (Belv 187), Middle (Belv 120, 83, 68) and Upper Miocene (Belv 54, 42, 32, 17); only Selenopemphix and Trinovantedinium are present.

Twenty-six gonyaulacoids taxa have been identified; they are particulary frequent in the Upper Burdigalian (Belv 187), Langhian (Belv 120), Lower Serravallian (Belv 83) and Lower Tortonian (Belv 54); they can be correlated to the main transgressions of the LTB. They are absent in Belv 237, 7 and Pa1; in other samples they are scarce $(\mathrm{n}<50)$. During Upper Burdigalian, Polysphaeridium zoharyi, Systematophora placacantha, Lingulodinium sp., Operculodinium israelianum and Spiniferites ramosus are represented. In the Langhian, Apteodinium australiense is very abundant; Lingulodinium sp., Polysphaeridium sp. and S. ramosus are common. In the Serravallian, Spiniferites/Achomosphaera, Hystricosphaeropsis obscura, Lingulodinium machaerophorum and Operculodinium israelianum are frequent. During Tortonian Lingulodinium machaerophorum, Homotryblium vallum, Spiniferites/Achomosphaera, S. pseudofurcatus and Operculodinium israelianum are common.

\section{ISOTOPIC AGES (Fig 2, 3)}

${ }^{87} \mathrm{Sr} /{ }^{86} \mathrm{Sr}$ age of eight mollusc shells, collected in the bottom, middle and upper part of the miocene sucession, were obtained by H. Elderfield (Cambridge University). In the Lower and Middle Miocene the ages agree quite 
well with the biostratigraphy, but for the Upper Miocene the ages given by the Howarth and Mcarthur's table (1997) fit better with the biostratigraphic data.

\section{CONCLUSIONS}

Belverde borehole (Pais et al., 2002) with a length of $620 \mathrm{~m}$, crossed $130 \mathrm{~m}$ of Plio-Pleistocene and $460 \mathrm{~m}$ of Miocene deposits. Classical lithostratigraphic units (Cotter, 1956) established for Lisbon region were recognized.

Planktonic biozones N6, N7, N8, N9, N10, N11-13 and N16 were identified.

The oldest Miocene depositional sequence known in Lisbon (SD A1) seems not to be represented in the Belverde Borehole. On the other hand, the youngest Miocene sediments from the borehole gave Neogloboquadrina acostaensis and Neogloboquadrina humerosa, which were not known in the outcrops.

The relative abundance of dinoflagellate cysts indicates a fluctuating marginal littoral to shallow marine depositional environments during the late Burdigalian through Tortonian. The presence of peridinioids (and scarce acritarchs) in some samples of the Upper Miocene (Belv 54, 42, 17) suggests an inshore to brackish environment (Sousa and Pais, 2002).

Minimum values of gamma ray fit well with the boundaries of depositional sequences previously defined for the Lower Tagus Basin (Antunes et al., 1999, 2000; Pais et al., 2002). A correspondence between depositional sequences and natural gamma ray cycles was established.

${ }^{87} \mathrm{Sr}{ }^{186} \mathrm{Sr}$ ages obtained by H. Elderfield (Cambridge University) fit well with the biostratigraphy for the Lower an Middle Miocene. For the Upper Miocene values given by Howarth and Mcarthur's table (1997) are closer to the biostratigraphic interpretation.

\section{AKNOWLEGMENTS}

Project aproved by the "Fundação para a Ciência e a Tecnologia" and by the POCTI cofunded by the EC FEDER Program (Portugal): "POCTI/32345/CTA/2000 - Recognition of the Miocene of the distal region of the Lower Tagus Basin through a borehole with continuous sampling.

\section{REFERENCES}

Antunes, M.T., Legoinha, P., Nascimento, A. and Pais, J. 1996. The evolution of the Lower Tagus basin (Lisbon and Setúbal peninsula, Portugal) from Lower to earlier Middle Miocene. Géologie de la France, 6, 59-77.

Antunes, M. T., Elderfield, H., Legoinha, P., Nascimento, A. and Pais, J. 1999. A Stratigraphic framework for the Miocene from the Lower Tagus Basin (Lisbon, Setúbal Peninsula, Portugal). Depositional sequences, biostratigraphy and isotopic ages. Revista de la Sociedad Geológica de España, 12, 3-15.

Antunes, M. T., Legoinha, P., Cunha, P. and Pais, J. 2000. High resolution stratigraphy and Miocene facies correlation in Lisbon and Setúbal Peninsula (Lower Tagus basin, Portugal. Ciências da Terra (UNL), 14, 183-190.

Cotter, J.C.B. 1956. O Miocénico marinho de Lisboa. Сотиnicações dos Serviços Geológicos de Portugal, XXXVI, suplemento, $170 \mathrm{pp}$.

Howarth R. J. and Mcarthur J. M. 1997. Statistics for strontium isotope stratigraphy. A robust LOWESS fit to the marine Sr-isotope curve for 0 - $206 \mathrm{Ma}$, with look-up table for the derivation of numerical age. Journal of Geology, 105, 441-456 (look-up table: version 3:10/99).

Legoinha, P., Sousa, L., Pais, J., Ferreira, J. and Rita Amado, A. 2002. Miocene lithological, foraminiferal and palynological data from the Belverde borehole (Portugal). XVIII Jornadas de la Sociedad Española de Paleontología, II Congreso Ibérico de Paleontología, RCANS Interim-Colloquium, Libro de resúmenes, Salamanca. 196-197.

Pais, J. 2004. The neogene of the Lower Tagus Basin (Portugal). Revista Española de Paleontología, 19, 229-242.

Pais, J., Lopes, C. S., Legoinha, P., Ramalho, E. Ferreira, J., Ribeiro, I., Amado, A. R., Sousa, L., Torres, L., Baptista, R. and Pena dos Reis, R. 2002. The Belverde Borehole (LTB, Setúbal Península, Portugal). XVIII Jornadas de la Sociedad española de Paleontología, II Congreso Ibérico de Paleontología, RCANS Interim-Colloquium, Libro de resúmenes, Salamanca, 198-199.

Sousa, L. and Pais, J., 2002. First data on palynology of the Belverde borehole (Lower Tagus Basin, Setúbal Peninsula, Portugal). XIV Simposio APLE, Salamanca, 144-146.

Manuscrito recibido: 20 de febrero, 2003 Manuscrito aceptado: 3 de septiembre, 2004 